\title{
Dramatic Theory in the Prologues of Giovan Maria Cecchi*
}

\section{Konrad Eisenbichler}

In the prologues to his plays, Giovan Maria Cecchi (1518-1587), ${ }^{1}$ the most prolific of sixteenth-century Florentine dramatists, makes several references to the basic characteristics of certain dramatic genres which were then in vogue and which some more than others, he himself used. The genre which he discusses the least, and which in fact he used only once, is tragedy. In the prologue to the sacred drama La morte del re Acab (1559), Cecchi remarks that tragedy demands far too many parts and is impossible to present as the Romans or Athenians used to, therefore it is best left alone (1895 ed., Vol. I, p. 503). We may detect in such a comment Cecchi's desire, in line with Olindo Guerrini's characterization of him as a quiet bourgeois, to remain outside the literary debates which were raging at the time. ${ }^{2}$

The one tragedy Cecchi did write, Datan e Abiron, was composed after 1580, that is very late in Cecchi's career, and at a time when his vast dramatic output would grant him the confidence to attempt such a genre. His only comment pertinent to our question is that the work about to be presented will perhaps be as useful as it is lacking in happiness (1895 ed., Vol. II, p. 227). Tragedy, therefore, is not to contain humour but rather, in inciting weeping and sorrow, it eventually proves to be of benefit to the spectators by presenting them with an example not to be followed. In these post-Tridentine times it is not surprising that in the prologue to Datan e Abiron Cecchi claims to have sought to show the folly of ambition and rebellion, both civil and religious:

Avvenga che di qui potrà impararsi

Quanto dispiaccia al Ciel l'ambizione,

E 'l fare scisma contro al suo prelato

$\mathrm{O}$ altro suo signore: a cui che osta,

Si contrappone a Dio, di cui l'esempio

Ei tiene in terra. . . . (1895 ed., Vol. II, pp. 227-28) 
A little more attention is paid to the drammi sacri, plays, usually in five acts, which contain religious subject matter. Although in La morte del re Acab (1559) one character of the prologue calls them "misterio da zazzeroni," a reference to the medieval drama which had by now been superceded by the classical and humanistic theatre, Cecchi claims that they too have their merits, especially since they are a "cosa di mezzo" between comedy and tragedy. At times when one cannot present a comedy and does not know how to present a tragedy, the dramma sacro is a viable alternative (1856 ed., Vol. I, pp. 501, 503). Ten years later, in La coronazione del re Saul (1569), Cecchi mentions further characteristics of this genre. It permits:

... suntüosità di vesti, molti-

tudine di persone, abbigliamenti

Ricchi e azion che abbin dell'eroico

E del rappresentato. (1895 ed., Vol. II, p. 10)

All these, Cecchi says, are more suited to an open-air theatre, as was the case for that particular performance, where pomp and spectacle were given full reign. ${ }^{3}$ Comedy, on the other hand, is to be performed indoors, for it deals with vicissitudes of the common people. Accordingly, costume is to be modest and the number of actors on stage is to be limited, usually to not more than four at a time (La morte del re Acab, 1586 ed., Vol. I, p. 503).

Horace had said that comedy had a dual purpose: to please and to teach. Cecchi accepted this canon, especially as the years went by. In the earlier plays, he usually placed the greater emphasis on the pleasing aspect. In La dote (1554), there is merely the comment "Per soddisfare adunque ai più, $\mathrm{e}^{\prime}$ vogliono / Darvi la Dote in somma" (1883 ed., p. 20), a rather general and vague indication that the play is intended to provide some merriment for those present, and nothing more. However, in I Dissimili (1548), there is a suggestion of didactic purpose: the play is intended "come per antidoto e medicina" for fathers and for young men who seek a wife so that they may learn that to bring up children too strictly or too liberally leads to the destruction of the honour and of the faculties of the father (1883 ed., p. 219). The lighter aspect of entertainment is still present and is directed to the younger section of the audience. Especially for this group Cecchi has included several situations which will give rise to laughter. Cecchi's most famous play, L'Assiuolo (1549), does not, in the prologue, make any claim to provide either pleasure or edification. The discussion centres instead on the contents of comedy in general and of $L^{\prime} A s s i-$ 
uolo in particular (1883 ed., pp. 269-70). If any preference is to be detected, it is probably in favour of a concept of comedy as entertainment rather than edification, and, generally speaking, this is true of most of Cecchi's erudite comedies. This entire group, in fact, is intended as entertainment, and any amount of edification which may be found in it is either of secondary importance or purely a conventional statement that seems to carry little conviction on the part of the author.

It is not until Cecchi begins to compose other genres that his purpose in writing a play undergoes a change. With the first sacred drama La morte del re Acab (1559), the audience itself begins to have a bearing on the type of spectacle that is offered:

... Ella fia cosa degna

$\mathrm{Da}$ recitarsi a persone che abbino

Discorso e discrezion. . . . (1856 ed., Vol. I, p. 501)

Not only this, but the locale itself, a convent school, dictates a religious subject matter which in turn provides more example to follow than entertainment to enjoy. Since the play was composed at a time when the Council of Trent was in full operation (1545-1563), the statement of intent seems to acquire more importance than would at first appear:

E vogliam, se ne fia dato silenzio,

Recitare una istoria santa, in cui

Sotto lo esempio del Re Acab e della

Scellerata sua donna, e delle loro

Subite e violente morti, chiaro

Si conosca che il giusto Dio punisce

Severamente chiunche la sua santa

Religion perseguita. (1856 ed., Vol. I, p. 502)

Coming after fifteen secular comedies, this drama, which differed so much from Cecchi's usual compositions, needed further recommendation from the author, therefore Cecchi stressed the benefit which it would provide, thus making a comment on the small didactic value of his previous plays.

La Coronazione del re Saul (1569) is, as are many other previous works, meant "per dilettare e per giovare" (1895 ed., Vol. II, p. 11). However, the place of performance, a school instituted by the Archbishop Antonin Santo for the instruction of youths in the principles of Christian piety, dictates that the plot deal with a sacred subject which will serve to instruct in the ways of God. Hence, the author begins to call his play "cristiano ed onesto 
tratteni- / mento" and points out that, above all things, God expects obedience from us (1895 ed., Vol. II, p. 11). It becomes clear that in post-Tridentine times the didactic stress on religious subservience and on piety replaces the previous emphasis on pleasant secular entertainment.

Since the actors are now either young students in religious schools or nuns of the convent where the play is being performed, the purpose of the production with respect to these performers is discussed. In La Serpe ovvero la mala nuora (1574), Cecchi points out that the youths, wishing to entertain themselves honestly and learn something from their efforts, to say nothing of providing entertainment for the spectators, have chosen to present a small but honest farce. The theme of the benefits which the actors themselves can derive from the performance begins to appear quite often in the prologues. At first it is merely a suggestion that the production is honest entertainment, but later in the prologue Cecchi stresses the importance of relaxation by narrating the story of the abbot San Benedetto and the archer. Its moral is that just as a bow must not be kept continually taut so as not to diminish its strength, so friars, and by extension nuns, need to give themselves to secular entertainment occasionally so as to relax and be able to return to their spiritual duties with renewed vigour (1895 ed., Vol. II, pp. 157-58). ${ }^{4}$ No longer is the play only meant to entertain and instruct, but is, to a certain extent, physically therapeutic as well. The Horatian dual purpose of comedy has not only switched emphasis from the dilettare to the giovare, but has added a hitherto unmentioned aspect to the word, that of benefit to the performers as well as to the spectators.

According to Cecchi, comedy acquires new attributes which are complementary to it. As he indicates, there is more to comedy than might at first be surmised. The effect it has on the spectators and its own value as an artist's creation are dependent on the finer details, on the ornaments, as it were, that are used to embellish it. In the prologue to L'Ammalata (1555), for example, Cecchi draws a parallel between comedies and women, saying that:

\section{Le comedie}

Son donne come l'altre, le quai senza

Lisci, pezzetta e belle vesti, sono

Befane per lo più; ma rivestite

Ed azzimate, paiono una bella

Cosa. (1856 ed., Vol. II, p. 94)

In this simile, Cecchi is perhaps indicating his own thoughts about the necessity of revision and polish in any creative work, 
something which he himself, in the course of his numerous compositions, was not always able to do. There are many references in his prologues to the short amount of time it took him to write his plays and to the fact often he found himself unable to revise and correct them. ${ }^{5}$ Le Cedole $(1574 \times 79)$ is a case in point: it had supposedly been written in a mere four days and had then been given to the players without the necessary revisions and corrections. Only late in his life was Cecchi able or willing to return to his earlier works and re-examine them, and this was primarily dependent on his desire to recast his prose comedies, published in 1550 by Gabriel Giolito de' Ferrari, into verse in preparation for their 1585 edition by Bernardo Giunti. ${ }^{6}$

In the prologue to Gli Sciamiti (1558), Cecchi asks his audience to remain quiet during the course of the performance and to withhold any comments until the end of the play. Drawing a parallel with the card game of Germini, a Cinquecento form of Tarot, he points out:

Chè le comedie son simili a' Germini,

Il giuoco delli quali è bello e piacemi

Solo per il gridar, e per le dispute

Che si fanno, fornito il giuoco. (1856 ed., Vol. I, p. 291)

The discussions of new plays, however, could often reflect serious disagreements, especially when imitation from the ancients was involved or when the classical canons of dramaturgy, as envisioned by sixteenth-century theorists, were being considered. It seems that Cecchi was able to avoid major confrontations with other writers or critics. Perhaps his easy-going nature was the means by which he was able to avoid attack. Nevertheless, Cecchi did imitate the ancients and did speak out on the matter. In some of his erudite comedies he mentions in the prologue the Latin source from which events or even the plot have been taken. The important question, he claims, is not so much the actual derivation of the play itself, but the dramatist's open acknowledgement of his sources:

Ora ciascheduno pigli la parte sua senza saper se la viene dal greco o dal latino; bastandogli che l'autore confessi che ciò che ci ha questa Commedia di buono, l'ha imitato da Terenzio, seguendo in ciò la openione di quelli maestri migliori delli quali egli desidera d'esser discepolo. (I Dissimili, 1883 ed., p. 220)

For Cecchi, as for most writers of the sixteenth century, imitation is the fundamental technique of their art. He is careful, how- 
ever, to distinguish between borrowing and stealing. In the first prologue to Le Pellegrine (1567), he claims that imitation is not theft, and then proceeds to explain how all the better poets imitate. Not only they, but painters and sculptors as well, when they see a beautiful thing, seek to copy it in a conscious and deliberate manner (1885 ed., p. 10). There is, early in Cecchi's career, a safeguard against blind imitation which is nothing more than outright plagiarism. In the prologue to La Dote (1544) Cecchi dissociates himself from certain ladroncelli who steal not only plots but entire comedies from Plautus and then claim them as their own by virtue of some insignificant original fragment which they have managed to weave into the play. He goes on to claim that he has taken the plot from Plautus, and says that he will do the same in the future, because he has seen the greatest playwrights do the same, be they modern or ancient. Plautus and Terence borrowed from the Greeks, the moderns do the same from the Romans, and there may conceivably be a time when future writers will pay the same compliment to the Florentines. ${ }^{7}$ At this point Cecchi repeats Terence's dictum that since there is nothing new under the sun one is obliged to follow the example of previous writers (1883 ed., p. 21).

In L'Assiuolo (1549) Cecchi claims that he has stayed clear of imitation by presenting an event which occurred recently in Pisa involving certain students at the university. Although Cecchi's claim is debatable for there are obvious borrowings from Boccaccio and from contemporary writings, the statements he makes when pointing out the classical aspects which he has omitted give us a view of several loci communes that were often exploited. L'Assiuolo, he says, does not depend for its "first-mover" incident on the Sack of Rome, or the Siege of Florence, or any action which may result in the dispersal of persons and families. Nor does it end in marriages, nor in the discovery of lost children or relatives. Nor is there anyone lamenting the loss of children or relatives, nor anyone seeking to be married or to marry someone off. These, in fact, were the starting points of several of Cecchi's erudite comedies and the solution to the disorder was an agnition which came as a deus ex machina to resolve and normalize the situation. ${ }^{8}$

There are certain ground rules for comedy which Cecchi tries to observe. When he finds himself straying from them, as in the case of L'Assiuolo, whose plot is not taken from the Latins and where certain loci communes are not present, he finds it necessary to justify himself before the spectators. In this play Cecchi mentions that his desire to present an event which actually occurred a short time before leads him to forego the usual incidents of comedy and 
to employ the kind of language which at times may appear a little too licentious but which respect for reality demands. There is a charming apology in L'Ammalata (1555), where Cecchi mentions that the comedy will not follow all the rules of the genre but, he then points out, neither Plautus nor Terence, to say nothing of Aristophanes or Lavinius, always followed the rules. Therefore, even if they were to complain about the author's disrespect for dramatic norms, he could, in all fairness, tell them to mind their own affairs (1856 ed., Vol. II, p. 95).

When it comes to the farce, the prologue of La Romanesca (1585) provides the most comprehensive definition of the genre. Cecchi begins by pointing out that no worthy playwright has yet composed in this manner. There may be present in this comment an indication that he is about to rectify the situation himself and be the first dramatist worthy of the name to write farces. He then continues with a description of farce saying:

\section{La farsa è una terza cosa nuova}

Tra la tragedia e la comedia: gode

Della larghezza di tutte e due loro,

E fugge la strettezza lor; perchè

Raccetta in sè li gran signori e principi.

Il che non fa la comedia: Raccetta,

Come ella fusse o albergo o spedale,

La gente come sia, vile e plebea;

Il che non vuol mai far donna tragedia:

Non è ristretta a' casi: chè gli toglie

E lieti e mesti, profani e di chiesa

Civili, rozzi, funesti e piacevoli:

Non tien conto di luogo: fa il proscenio

Ed in chiesa ed in piazza e in ogni luogo.

Non di tempo: onde se ella non entrasse

In un dì, lo torrebbe in due e in tre. (1880 ed., p. 8)

Cecchi's earlier comment, in La morte del re Acab, with respect to the sacred drama being a midway ( $\cos a$ di mezzo) between comedy and tragedy has now, in a somewhat modified form, been also attributed to the farce. Perhaps the restriction of religious subject matter was somewhat too constrictive for Cecchi and he preferred to opt for the liberty which farce offered. Cecchi's own words in this prologue point out that he appreciated the freedom of not observing the unities of time and place. No longer was he restricted in subject matter, in setting, or in time; all he had to be careful to observe was the decorum of each personage, that is to say that each person on stage speak and behave as he would according to his rank and character. 
In a century in which imitation of the classics was the basic rule of thumb in all the arts, it would have been difficult for Cecchi to devote himself seriously to the farce had he also not been able to point out this genre's close relationship to the classical theatre. He responds to the accusation that the ancients did not use this form with a three-fold argument. First, he claims that good modern dramatists do write farces. This is a point against imitation and in favour of originality, but it is also a contradiction of his earlier statement in the very same prologue to the effect that no worthy modern writer had used the farce. If Cecchi really thought himself to be the first modern of worth to use this genre, the contradiction is resolved. Cecchi's second argument is somewhat weaker, for it relies totally on proposing alternative explanations rather than providing facts. Aristotle's silence with respect to the farce is explained away by saying that either the genre did not exist in Aristotle's time or his discussion of it was contained in those books of his Poetics which have been lost. Neither proposition can be supported with factual evidence, and therefore Cecchi finds himself drawing parallels with printing and compasses, neither of which were mentioned or known by Aristotle, but which no one would consider unsuitable for use. The third argument is the most factual and most direct. Cecchi states that the Emperor Caligula had a writer of farces burnt alive in the theatre for daring to write one where a verse had a double meaning. Thus farces did exist in classical time and may be used by respected playwrights (La Romanesca, 1880 ed., pp. 8-10).

There are other times when Cecchi makes references to the characteristics of farces. In La Serpe ovvero la mala nuora (1574), his first farce, Cecchi says that this three-act composition was written "in un tirar di penna, / Senza pensarci troppo sopra," (1895 ed., Vol. II, p. 157), just for the purpose of providing some exercise for certain fanciulli who hope in the future to be able to devote themselves to greater things. The dramatist's opinion that farce is somewhat inferior in genre is evident, but it is not surprising since this is his first attempt at it. Such an attitude had in fact already been encountered in his first sacred drama, La morte del re $A c a b$ when he had referred to such compositions as "misterio da zazzeroni" (1856 ed., Vol. I, p. 501). Noteworthy, however, is the implication that farce is primarily a didactic genre.

The prologue to La Serpe ovvero la mala nuora continues with further excuses meant to counter any possible criticism. Cecchi points out the young age and little experience of the actors, thus inviting the audience to overlook faults in the presentation. If the play itself should seem weak, the spectators should be aware that 
the dramatist has sought to accomodate the matter to the players, to write a farce for children who cannot be expected to be able to cope with a comedy.

The Horatian pleasure/profit duality reappears in the farces. In L'Acqua-vino (1579) Cecchi says he is presenting "una farsa non molto lunga, ma s'io non m'inganno, vi parrà breve, e utile e piacevole" (1869 ed., p. 3). The didactic element is to be found in the illustration of the Saviour's goodness, of the value of Christian courtesy, of the effects of the Virgin's intercession with her Son, and of the power of God to turn our tears of suffering into the wine of devotion and charity. Entertainment is provided by the players who are mostly new to the art and who wish to be able to improve themselves through practice. The farce is also seen as a vehicle through which an aspiring actor may acquire experience that will eventually allow him to perform in comedies, "che bisogna esser prima discepolo e poi maestro" (1869 ed., p. 4).

At times, however, it was the nuns who presented the farces and acted in them within their own convent's walls. Since the earlier view which saw the farce as a vehicle for training children becomes inappropriate to an audience consisting of nuns, Cecchi proposes another purpose for the genre. In L'Acquisto di Giacobbe (1580X87), the play is intended as a past-time for the nuns, as a form of relaxation, and any failures in the presentation are dismissed by saying that for such trifles the nuns "non hanno voluto/ Scorticarsi" (1895 ed., Vol. I, p. 98).

Having arrived at this point in our examination, a number of conclusions become evident. One of the first is that Cecchi, as a successful and prolific writer, was more concerned with the impact of his plays on his audience than with debates on the formal minutiae of drama. Only in La morte del re Acab and in La Romanesca did he attempt to speak to that question. However, even in these cases, Cecchi was not as concerned with deliberations on form as he was with deliberations on the suitability of the genre. In fact, the prologue to La Romanesca, cited as the most comprehensive definition of sixteenth century farce, spends more time on the defense of the genre than on its definition.

Examining the early erudite comedies of the 1540 's and proceeding through into the 1550 's, the reader becomes aware of a growing stress on the Horatian delectare/docere maxim. When this genre is abandoned in the 1560's and 1570's in favour of sacred plays and farces, it becomes evident that in his secular theatre Cecchi had been paying mere lip-service to Horace. The situation is soon remedied, so much so that the dramatist begins to suggest, if not state outright the moral or the purpose of his plays. 
The remarkable development at this point is the growth of an awareness of the effects of drama on the actors: theatre is a school in which young minds and bodies are exercised.

From what has been said above, it becomes clear that Cecchi was conscious of the limitations and possibilities of the different theatrical forms. In the first fifteen years of his career (1544-1559) he accepted the norms of erudite comedy and wrote his plays to suit the secular intentions of the confraternities that commissioned them. When both the spirit of the age and his audience began to change, Cecchi adapted his skills to the new demands. This must have been a pioneering process for his concept of theatre, as can be seen by the numerous occasions on which he sought to inform his audience of the nature of the play to be performed and of the genre to which it belonged. From these comments it becomes evident that Cecchi sought to differentiate between the genres and, when finally he dedicated himself to farces, to suggest an increased respectability for them. In fact, as his thoughts on comic theory developed, Cecchi began to envision farce as the ideal form to accomodate an expanded concept of theatre while at the same time providing renewed inspiration in conformity with the time. In this manner his comic theory sought to keep abreast of the changing cultural climate in late sixteenthcentury Florence.

\section{University of Toronto}

\section{NOTES}

*The present article is a much shorter version of a paper read at the April 10, 1980 meeting of the Toronto Renaissance and Reformation Colloquium.

1 Dates in parentheses indicate the year in which the play was composed; all of Cecchi's plays seem to have been commissioned and seem to have been performed within a few months of their composition. To avoid excessive footnoting, references to Cecchi's plays will be followed by a parenthesis containing the year of publication and page number of the edition used. The editions, in chronological order, are: Giovan Maria Cecchi, Commedie inedite (Firenze, 1855).

- Commedie (Firenze, 1856), 2 vols.

- Commedie (Napoli, 1869).

- L'Acqua-vino (Ferrara, 1876).

- La Romanesca (Livorno, 1880).

- Commedie (Milano, 1883).

- La Dolcina (Bologna, 1883).

- Drammi spirituali inediti (Firenze, 1895-1900), 2 vols.

2 Olindo Guerrini, "Prefazione" to Giovan Maria Cecchi, Commedie (Milano, 1883), p. 7. 
3 It seems that the Grand Duke Cosimo 1, his son Ferdinando and perhaps even the Archduke Karl of Austria attended the 1569 performance of La Coronazione del re Saul (See Raffaello Rocchi's notes in the Commedie spirituali inedite, 1895 ed., Vol. II, p. 154, n. 4).

4 The story of San Benedetto and the archer is mentioned in the prologue of three other plays by Cecchi; they are L'Acquisto di Giacobbe (1895 ed., Vol. I, pp. 96-97), Il Putto risuscitato (1895 ed., Vol. I, p. 357) and L'Acqua-vino (1876 ed., pp. 5-7).

5 La Serpe ovvero la mala nuora was written "in un tirar di penna." The prologue to Le Maschere, a comedy which Cecchi took only six days to compose, informs us that "e' non fe' mai alcuna / Ch'e' vi mettesse più di dieci giorni."

6 The plays which Cecchi versified and republished are: La Dote, La Moglie, La Stiana, Gl'Incantesimi. Ugo Scoti-Bertinelli examines the prose comedies and compares them with their subsequent versification in his work Sullo stile delle commedie in prosa di Giovan Maria Cecchi (Città di Castello, 1906).

7 In fact, Cecchi himself was paid the compliment of having imitators, both in Florence and abroad. Anton Francesco Doni rewrote L'Assiuolo, changing the name of the characters and introducing a moral element, but his version, entitled Lo Stufaiolo o l'azaro lost much of the natural charm of the original. In Spain Lope de Rueda (1510? - 1565) made liberal use of Cecchi's Il Servigiale for his own comedy Armelina.

8 These starting points and resolutions are quite common on Cecchi's erudite plays. In I Rivali (1556), the old man Basilio recognizes the daughter he had lost when his house burned down in Siena. In Gli Sciamiti (1558) a Sienese exile realizes that one of the three girls is his daughter whom he had never seen before. In Il Martello (1561) Papera recognizes in Selvaggia her own daughter from her first husband. In L'Ammalata (1555) Marisco recognizes in his healer his wife, whom he had previously ordered killed by a servant, and in a servant he recognizes his son, whom he had lost at the time of the supposed killing of his wife. In La Maiana (1550-51) Porzia turns out to be Bartolo's daughter and hence Giulio's sister. 